\title{
PENINGKATAN KETERAMPILAN PENELITIAN TINDAKAN KELAS DALAM PENGEMBANGAN KEPROFESIAN BERKELANJUTAN MELALUI WORKSHOP DAN PENDAMPINGAN BAGI GURU SEKOLAH DASAR
}

\author{
Wahyudi, Rokhmaniyah, Kartika Chrysti Suryandari
}

\section{Universitas Sebelas Maret}

\section{Sejarah Artikel \\ Diterima 1 Juli 2017 \\ Disetujui 25 Julil 2018 \\ Diterbitkan 1 Agustus 2018}

Kata Kunci

ptk, workshop, pendampingan
Korespondensi Penulis wahyudi@fkip.uns.ac.id

\begin{abstract}
Abstrak
Tujuan penelitian ini adalah (1) mendeskripsikan kegiatan workshop dan pendampingan, (2) meningkatkan keterampilan melaksanakan PTK, (3) menemukan kendala dan solusi pelaksanaan workshop dan pendampingan pada peningkatan keterampilan PTK bagi guru SD. Penelitian ini menggunakan desain penelitian kualitatif dengan jenis Action Research dengan metode:workshop dan pendampingan. Penelitian ini dilaksanakan di wilayah UPT Disdikpora Kecamatan Kebumen - Kabupaten Kebumen, melibatkan 40 guru SD. Teknik pengumpulan data menggunakan metode workshop dan pendampingan, observasi, wawancara, dan unjuk kerja. Data dianalisis secara deskriptifkualitatif. Hasil penelitian adalah: (1) Kegiatan workshop dilaksanakan sebelum pendampingan dengan materi: teknik perumusan pemasalahan PTK, teknik penyusunan proposal PTK, teknik pelaksanaan PTK, (d) teknik pelaporan PTK, (e) teknik penulisan publikasi ilmiah, dan (f) teknik penilaian angka kredit.; (2) Metode workshop dan pendampingan dapat meningkatkan pemahaman dan Keterampilan PTK dalam Pengembangan Keprofesian Berkelanjutan bagi Guru SD; (3) Kendala kegiatan Workshop dan Pendampingan adalah: beberapa guru kurang fokus, kurang menguasai TIK, kurang aktif, beberapa guru masih memerlukan pendampingan yang lebih intensif. Solusinya: kegiatan Workshop dan Pendampingan dilaksanakan pada awal semester, guru perlu pendampingan orang yang menguasai TIK, waktu pelaksanaan tugas diperpanjang, perlu pengelompokan guru berdasarkan kecapatan berfikir/usia. Kesimpulan penelitian ini adalah Metode workshop dan pendampingan dapat meningkatkan pemahaman dan Keterampilan PTK bagi Guru SD.
\end{abstract}

\section{Cara Mengutip}

Wahyudi, Rokhmaniyah, Suryandari, K.,C. (2018). Peningkatan Keterampilan Penelitian Tindakan Kelas dalam Pengembangan Keprofesian Berkelanjutan Melalui Workshop dan Pendampingan Bagi Guru Sekolah Dasar. DWIJA CENDEKIA: Jurnal Riset Pedagogik, 2 (1), 90-98 


\section{PENDAHULUAN}

Guru adalah pendidik profesional yang mempunyai tugas, fungsi, dan peran penting dalam mencerdaskan kehidupan bangsa. Guru yang profesional diharapkan mampu berpartisipasi dalam pembangunan nasional untuk mewujudkan insan Indonesia yang bertakwa kepada Tuhan Yang Maha Esa, unggul dalam ilmu pengetahuan dan teknologi, memiliki jiwa estetis, etis, berbudi pekerti luhur, dan berkepribadian. Tidaklah berlebihan kalau dikatakan bahwa masa depan masyarakat, bangsa, dan negara, sebagian besar ditentukan oleh guru. Oleh sebab itu, profesi guru perlu ditingkatkan dan dikembangkan secara terus menerus dan proporsional menurut jabatan fungsional guru. Selain itu, agar fungsi dan tugas yang melekat pada jabatan fungsional guru dilaksanakan sesuai dengan aturan yang berlaku, maka diperlukan penilaian kinerja guru yang menjamin terjadinya proses pembelajaran yang berkualitas di semua jenjang pendidikan. Pelaksanaan penilaian kinerja guru dimaksudkan bukan untuk menyulitkan guru, tetapi sebaliknya penilaian kinerja guru dilaksanakan untuk mewujudkan guru yang profesional, karena harkat dan martabat suatu profesi ditentukan oleh kualitas layanan profesi yang bermutu. Selain hal tersebut penilaian kinerja guru juga untuk menunjukkan secara tepat tentang kegiatan guru di dalam kelas, dan membantu mereka untuk meningkatkan pengetahuan serta keterampilannya. Dengan demikian diharapkan dapat memberikan kontribusi secara langsung pada peningkatan kualitas pembelajaran yang dilakukan, sekaligus membantu pengembangan karir guru sebagai tenaga profesional. Untuk meyakinkan bahwa setiap guru adalah seorang profesional dalam bidangnya, maka penilaian kinerja guru harus dilakukan terhadap guru di semua satuan pendidikan formal yang diselenggarakan oleh pemerintah, pemerintah daerah, dan masyarakat. Guru dimaksud tidak terbatas pada guru yang bekerja di satuan pendidikan di bawah kewenangan Kementerian Pendidikan dan Kebudayaan, tetapi juga mencakup guru yang bekerja di satuan pendidikan di lingkungan Kementerian Agama. Hasil penilaian kinerja guru dan Evaluasi Diri digunakan untuk menyusun profil kinerja guru sebagai dasar penyusunan program Pengembangan Keprofesian Berkelanjutan. Hasil penilaian kinerja guru juga merupakan dasar penetapan perolehan angka kredit guru dari sub unsur pembelajaran/bimbingan dalam rangka pengembangan karir guru sebagaimana diamanatkan dalam Peraturan Menteri Negara Pendayagunaan Aparatur Negara dan Reformasi Birokrasi Nomor 16 Tahun 2009 tentang Jabatan Fungsional Guru dan Angka Kreditnya. Jika semua ini dapat dilaksanakan dengan baik dan obyektif, maka cita-cita pemerintah untuk menghasilkan" insan yang cerdas komprehensif dan berdaya saing tinggi" lebih cepat direalisasikan. Memperhatikan kondisi jabatan guru sebagai profesi dan kebijakan pemerintah dalam pengembangan profesi guru maka diperlukan pedoman pelaksanaan penilaian kinerja guru yang menjelaskan tentang apa, mengapa, 
kapan, bagaimana dan oleh siapa penilaian kinerja guru dilaksanakan. Penyusunan pedoman ini mengacu pada Peraturan Menteri Negara Pendayagunaan Aparatur Negara dan Reformasi Birokrasi No. 16 Tahun 2009 tentang Jabatan Fungsional Guru dan Angka Kreditnya sebagai acuan pelaksanaan penilaian kinerja guru di sekolah untuk mempermudah proses penilaian kinerja guru.

Hasil pengamatan dan studi pendahuluan di wilayah UPT Dinas Dikpora Kecamatan KebumenKabupaten Kebumen, menunjukkan bahwa sebagian besar guru, khususnya guru sekolah dasar, dalam pengembangan karier dan kepangkatan masih menghadapi kendala. Hal ini terlihat dari banyaknya guru yang mengalami kesulitan untuk naik jabatan dan pangkat, terutama pada golongan IV. Berdasarkan kondisi rill di lapangan tersebut, peneliti terpanggil untuk menindaklanjuti dan memecahkan permasalahan tersebut, yaitu untuk meningkatkan kompetensi guru sekolah dasar tentang pemahaman dan keterampilan melaksanakan Penelitian Tindakan Kelas, menyusun laporan Penelitian Tindakan Kelas, serta menyusun naskah artikel jurnal ilmiah dari hasil penelitian dengan menggunakan metode workshop dan pendampingan.

Berdasarkan analisis situasi di atas, maka dapat disajikan rumusan masalah penelitian sebagai berikut: (1) Bagaimana kegiatan workshop dan pendampingan yang dapat meningkatkan keterampilan Penelitian Tindakan Kelas dalam pengembangan keprofesian berkelanjutan bagi guru sekolah dasar?, (2) Apakah melalui workshop dan pendampingan dapat meningkatkan keterampilan Penelitian Tindakan Kelas dalam pengembangan keprofesian berkelanjutan bagi guru sekolah dasar?, (3) Apakah kendala dan solusi pelaksanaan workshop dan pendampingan pada peningkatan keterampilan Penelitian Tindakan Kelas dalam pengembangan keprofesian berkelanjutan bagi guru sekolah dasar?

\section{METODE PENELITIAN}

Kegiatan

Penelitian

ini menggunakan desain penelitian kualitatif dengan jenis penelitian tindakan (Action Research) dalam bentuk transfer ilmu pengetahuan dan teknologi dari perguruan tinggi kepada stake holder yang meliputi kegiatan: workshop, pelatihan, dan pendampingan.

Penelitian ini dilaksanakan di wilayah UPT Dinas Dikpora Kecamatan Kebumen - Kabupaten Kebumen yang melibatkan dua Gugus Kelompok Kerja Guru (KKG) di Kecamatan Kebumen, Kabupaten Kebumen, yaitu: (1) Gugus
Rujakbeling dan (2) Gugus Banyumudal pada tahun 2018. Subjek penelitian ini adalah guru sekolah dasar yang ada di wilayah dua gugus KKG tersebut sebanyak 40 guru sekolah dasar.

Penelitian ini menggunakan sumber data dari guru sekolah dasar, kepala sekolah dasar, dan peneliti. Teknik pengumpulan data penelitian ini adalah dengan metode workshop dan pendampingan, observasi, wawancara dan hasil unjuk kerja. Metode workshop dan pendampingan digunakan untuk membekali dan meningkatkan pemahaman tentang 
Penelitian Tindakan Kelas bagi guru sekolah dasar. Observasi atau pengamatan dilakukan untuk mengetahui kegiatan penelitian selama dilaksanakan, mulai dari tahap perencanaan, pelaksanaan, dan evaluasi. Hasil observasi ini digunakan untuk mendeskripsikan proses dan hasil kegiatan yang telah dilaksanakan. Teknik wawancara digunakan untuk mengetahui tingkat pemahaman, penguasaan materi dan tingkat kepuasan dalam kegiatan penelitian ini. Hasil unjuk kerja digunakan untuk mengetahui tingkat pemahaman dan keterampilan dalam pelaksanaan Penelitian Tindakan Kelas.

Untuk menjaga validitas data, digunakan teknik triangulasi sumber data dan triangulasi teknik yang melibatkan guru SD, kepala sekolah, dan teman sejawat. Analisis data yang digunakan dalam penelitian ini adalah analisis data deskriptif-kualitatif yang meliputi tiga alur kegiatan yang dilakukan secara bersamaan dan terus menerus selama dan setelah pengumpulan data yaitu (1) reduksi data, (2) penyajian data, dan (3) penarikan kesimpulan atau verifikasi data (Miles \& Huberman, 1992).

Indikator kinerja atau kriteria keberhasilan merupakan petunjuk atau tanda yang muncul sebagai wujud dari keberhasilan kegiatan penelitian. Peneliti menetapkan indikator kinerja sejak awal agar pada akhir pelaksanaan kegiatan dapat diketahui secara pasti apakah kegiatan yang telah dilakukan telah berhasil atau belum. Indikator kinerja yang ditetapkan adalah minimal $80 \%$ dari semua kegiatan dapat dilaksanakan dengan baik.

Prosedur penelitian ini diuraikan menjadi 3 bagian, yaitu (1) kegiatan workshop, (2) kegiatan pendampingan. Pada setiap bagian kegiatan melibatkan 4 tahapan, yaitu: (a) perencanaan, (b) pelaksanaan, (c) pengamatan, dan (d) refleksi/evaluasi.

\section{PEMBAHASAN}

1. Workshop dan Pendampingan PTK dalam Pengembangan Keprofesian Berkelanjutan bagi Guru SD.

Pada tahap perencanaan dilakukan beberapa kegiatan, yaitu (a) perencanaan sosialisasi kegiatan, penyebaran angket kebutuhan stake holder, dan pendataan peserta, (b) penyusunan struktur kurikulum workshop dan pendampingan, (c) penyiapan instrumen kegiatan,

perencanaan pelaksanaan kegiatan, dan (e) perencanaan evaluasi kegiatan.
Pada tahap pelaksanaan kegiatan, diawali dengan kegiatan sosialisasi dilaksanakan sebelum kegiatan pelaksanaan workshop dan pendampingan. Tujuan kegiatan ini adalah untuk memberikan penyamaan persepsi terhadap kegiatan yang akan dilaksanakan yang meliputi (a) latar belakang kegiatan, (b) tujuan keguiatan, (c) skenario kegiatan, dan (d) indikator keberhasilan kegiatan. Kegiatan sosialisasi dilaksanakan pada tanggal 24 Maret 2018 di dua gugus Kelompok Kerja Guru (KKG), yaitu Gugus Banyumudal dan Gugus 
Rujakbeling di wilayah UPT Dinas Dikpora Kecamatan Kebumen yang diikuti oleh 55 guru dan kepala sekolah dasar. Untuk mengetahui permasalahan dan kebutuhan guru sekolah dasar tentang penulisan Penelitian Tindakan Kelas (PTK), maka pada kegiatan sosialisasi tersebut dibagikan angket kebutuhan stake holder tentang permasalahan penelitian tindakan kelas. Untuk mengetahui tingkat peminatan terhadap kegiatan workshop dan pendampingan, maka pada kegiatan ini juga dilakukan pendataan. Dari hasil pendataan peserta diperoleh data 40 guru sekolah dasar yang mengikuti kegiatan workshop dan pendampingan.
Berdasarkan hasil angket kebutuhan tentang permasalahan Penelitian Tindakan Kelas, maka diperoleh data materi yang dilaksanakan pada kegiatan workshop dan pendampingan sebagai berikut: (a) konsep Penelitian Tindakan Kelas, (b) penyusunan proposal PTK, (c) pendampingan pelaksanaan dan pelaporan PTK, (d) penyusunan laporan PTK, (e) seminar hasil pelaksanaan PTK, dan (f) penilaian angka kredit jabatan fungsional guru.

Berdasarkan daftar kebutuhan guru sekolah dasar tentang pemahaman Penelitian Tindakan Kelas, maka dapat disusun struktur kurikulum kegiatan workshop dan pendampingan sesuai table 1 .

\begin{tabular}{lc} 
Tabel 1. Kurikulum Workshop dan Pendampingan \\
\multicolumn{1}{c}{ Materi Kegiatan } & Jam \\
\hline Workshop: & 2 \\
Permasalahan dalam PTK & 2 \\
Proposal PTK & 2 \\
Pelaksanaan PTK & 2 \\
Pelaporan PTK & 2 \\
Penulisan Publikasi Ilmiah: Artikel & \\
Ilmiah & 2 \\
Penilaian Keprofesian & \\
Berkelanjutan:PAK & \\
Pendampingan: & \\
Pelaksanaan PTK & 6 \\
Pelaporan PTK & 6 \\
Seminar Hasil PTK & 6 \\
Penulisan Artikel Ilmiah & 2 \\
$\quad$ Jumlah Jam & 32 \\
\hline
\end{tabular}

Kegiatan workshop dan
pendampingan 4 PTK
dilaksanakan selama 4 bulan $(8$
pertemuan), yaitu mulai bulan Maret
2018 sampai dengan bulan Juni
2018 , yang diikuti oleh 40 guru
sekolah dasar di Gugus
Banyumudal dan
Rujakbeling UPT Dinas Dikpora

Kecamatan Kebumen - Kabupaten Kebumen. Kegiatan workshop dan pendampingan dilaksanakan setiap hari Sabtu, mulai pukul 11.00 15.00 WIB, setelah selesai jam sekolah, sehingga kegiatan ini tidak mengganggu kegiatan dinas guru di sekolah. 
Kegiatan workshop dilaksanakan selama 3 pertemuan (12 jam) dengan menggunakan metode ceramah, tanya jawab, diskusi, dan pemberian tugas. Adapun materi workshop meliputi (a) teknik rumusan pemasalahan dalam PTK, (b) teknik penyusunan proposal PTK, (c) teknik pelaksanaan PTK, (d) teknik pelaporan PTK, (e) teknik penulisan publikasi ilmiah, dan (f) teknik penilaian angka kredit kenaikan jabatan fungsional guru. Sedangkan kegiatan pendampingan dilaksanakan setelah kegiatan workshop, dengan menggunakan metode pendampingan dan bimbingan individu. Metode ini digunakan untuk memberikan pelayanan bimbingan sesuai dengan kecepatan, kemampuan, dan permasalahan yang dihadapi oleh masing-masing guru. Kegiatan pendampingan dilaksanakan selama 5 pertemuan (20 jam). Pada kegiatan pendampingan ini melibatkan 3 dosen pendamping. Adapun materi pendampingan meliputi (a) pelaksanaan PTK di sekolah, (b) pelaporan PTK, (c) seminar hasil PTK, dan penulisan artikel ilmiah.

\section{Peningkatan Keterampilan PTK dalam Pengembangan Keprofesian Berkelanjutan melalui Workshop dan Pendampingan bagi Guru SD.}

Setelah kegiatan Workshop dan Pendampingan dilaksanakan sesuai dengan rencana kegiatan, maka selanjutnya dilakukan evaluasi dan refleksi terhadap kegiatan tersebut. Kegiatan evaluasi dan refleksi bertujuan untuk mengetahui perubahan pemahaman guru SD terhadap keterampilan PTK dalam Pengembangan Keprofesian Berkelanjutan. Selain itu, kegiatan evaluasi dan refleksi juga digunakan untuk menemukan kendala yang dihadapi pada kegiatan Workshop dan Pendampingan. Selanjutnya, dari kendala yang ditemukan akan dicaikan solusi untuk mengatasi kendala tersebut.

Berdasarkan

hasil pengumpulan data tentang pelaksanaan kegiatan Workshop dan Pendampingan, maka diperoleh data sesuai table 2.

Tabel 2. Hasil Workshop dan Pendampingan PTK

\begin{tabular}{lrr}
\hline \multicolumn{1}{c}{$\begin{array}{c}\text { Materi Workshop dan } \\
\text { Pendampingan }\end{array}$} & $\begin{array}{c}\text { Rata Skor } \\
\text { Awal }\end{array}$ & $\begin{array}{c}\text { Rata } \\
\text { Skor Akhir }\end{array}$ \\
\hline Kegiatan Pelatihan/Diklat & 1,95 & 3,23 \\
Permasalahan dalam PTK & 1,41 & 3,73 \\
Penyusunan Proposal PTK & 1,49 & 3,80 \\
Pelaksanaan PTK & 1,35 & 3,63 \\
Pelaporan PTK & 1,13 & 3,64 \\
Penulisan Publikasi Ilmiah: Artikel & 1,45 & 3,25 \\
Ilmiah & & \\
Penilaian Keprofesian & 1,23 & 3,68 \\
$\begin{array}{l}\text { Berkelanjutan } \\
\text { PAK Kenaikan Jabatan }\end{array}$ & 1,43 & 3,80 \\
Fungsional Guru & & \\
$\quad$ Rerata Skor Akhir & $\mathbf{1 , 4 7}$ & $\mathbf{3 , 5 7}$ \\
\hline
\end{tabular}

Keterangan:

Rerata Skor Akhir

1 = Kurang; 2 = Cukup; 3 = Baik; 4 = Baik sekali 
Dari data pada tabel 2 tersebut di atas dihasilkan peningkatan pemahaman dan keterampilan PTK dalam Pengembangan Keprofesian Berkelanjutan. Peningkatan pemahaman terjadi pada setiap aspek dari fokus penelitian, yaitu: (a) Kegiatan Pelatihan/Diklat/Sosialisasi dari rata-rata 1,95 menjadi 3,23 (Baik); (b) Permasalahan dalam PTK, dari rata-rata 1,41 menjadi 3,73 (Baik); (c) Penyusunan Proposal PTK, dari rata-rata 1,49 menjadi 3,80 (Baik); (d) Pelaksanaan PTK, dari rata-rata 1,53 menjadi 3,63 (Baik); (e) Pelaporan PTK, dari rata-rata 1,13 menjadi 3,64 (Baik); (f) Penulisan Publikasi IImiah: Artikel IImiah, dari rata-rata 1,45 menjadi 3,25 (Baik); (g) Penilaian Keprofesian Berkelanjutan, dari rata-rata 1,23 menjadi 3,68 (Baik); (h) Penilaian Angka Kredit Kenaikan Jabatan Fungsional Guru, dari rata-rata 1,47 menadi 3,57 (Baik). Dari kedelapan aspek yang diukur, maka dapat disimpulkan adanya peningkatan yang signifikan pada pemahaman dan Keterampilan PTK dalam Pengembangan Keprofesian Berkelanjutan bagi Guru SD. Hal ini terbukti dari rata-rata pemahaman dan keterampilan PTK terjadi peningkatan dari 1,47 (Kurang) menjadi 3,57 (Baik).

\section{Kendala dan Solusi Pelaksanaan Workshop dan Pendampingan PTK dalam Pengembangan Keprofesian Berkelanjutan bagi Guru SD.}

\begin{tabular}{lcr}
\multicolumn{1}{c}{ Kegiatan } & Workshop dan \\
Pendampingan & PTK dalam \\
Pengembangan & \multicolumn{2}{c}{ Keprofesian } \\
Berkelanjutan bagi Guru SD
\end{tabular}

dilaksanakan sesuai dengan perencanaan yang disusun, namun demikian dalam pelaksanaannya ditemukan beberaa kendala, yaitu: (a) beberapa guru kurang fokus dalam mengikuti Workshop dan Pendampingan, karena padatnya kegiatan di sekolah, (b) beberapa guru kurang menguasai TIK, (c) beberapa guru kurang aktif melaksanakan tugas Workshop dan Pendampingan, (d) beberapa guru masih memerlukan pendampingan yang lebih intensif, karena kecepatan berfiirnya berbeda. Adapun alternatif solusinya adalah: (a) kegiatan Workshop dan Pendampingan dilaksanakan pada awal semester atau hari libur sekolah, (b) guru perlu bantuan/ pendampingan orang yang menguasai TIK, (c) Waktu pelaksanaan tugas diperpanjang, (d) perlu pengelompokan guru berdasarkan kecapatan berfikir/usia. Selain kendala pada pelaksanaan kegiatan Workshop dan Pendampingan, maka ditemukan juga kendala dalam penguasaan materi Workshop dan Pendampingan, yaitu: (1) Kendala pada Kegiatan Pelatihan/Diklat/Sosialisasi adalah: (a) kurang mendapatkan sosialisasi tentang Pengembangan Keprofesian Berkelanjutan; (b) guru kurang berusaha mencari tahu tentang Pengembangan Keprofesian Berkelanjutan; (2) Kendala pada Permasalahan dalam PTK adalah: (a) guru kurang terbiasa melaksanakan perbaikan pembelajaran, (b) guru kurang terbiasa menganalisis masalah pembelajaran; (3) Kendala dalam Penyusunan Proposal PTK adalah: (a) guru merasa sulit menentukan 
judul penelitian, (b) guru kesulitan menyusun instrumen penelitian; (4) Kendala pada Pelaksanaan PTK adalah: (a) guru kurang menyiapkan perangkat penelitian, (b) guru kurang lengkap dalam Pengumpulan data penelitian; (5) Kendala pada Pelaporan PTK adalah: (a) guru kurang menguasai sistematika laporan penelitian, (b) tidak semua guru menguasai TIK; (6) Kendala pada Penulisan Publikasi IImiah adalah: (a) guru belum terbiasa melaksanakan seminar hasil penelitian, (b) guru belum menguasai teknik menyusun artikel jurnal ilmiah, (c) guru belum pernah melaksanakan publikasi ilmiah; (7) Kendala pada Penilaian Keprofesian Berkelanjutan adalah: (a) guru kurang memahami jenisjenis Penilaian Keprofesian Berkelanjutan; (8) Kendala tentang Pemahaman penilaian Angka kredit adalah: (a) guru kurang memahami teknik penilaian angka kredit kenaikan jabatan, (b) guru kurang lengkap dalam pengumpulan berkas administrasi penilaian Angka Kredit untuk kenaikan jabatan.

Adapun alternatif solusinya adalah:

(1) Solusi untuk Kegiatan Pelatihan/Diklat/Sosialisasi adalah: (a) perlu sosialisasi tentang Pengembangan Keprofesian Berkelanjutan; (b) perlu bimbingan mencari literatur tentang Pengembangan Keprofesian Berkelanjutan; (2) Solusi untuk
Permasalahan dalam PTK adalah: (a) diberi pemahaman dan latihan tentang perbaikan pembelajaran, (b) diberi pemahaman dan latihan menganalisis masalah pembelajaran; (3) Solusi untuk Penyusunan Proposal PTK adalah: (a) pembimbingan dan pendampingan menentukan judul penelitian, (b) pembimbingan dan pendampingan menyusun instrumen penelitian; (4) Solusi untuk Pelaksanaan PTK adalah: (a) guru lebih menyiapkan perangkat penelitian, (b) guru lebih teliti dan lengkap dalam Pengumpulan data penelitian; (5) Solusi untuk Pelaporan PTK adalah: (a) Pemahamana tentang sistematika laporan penelitian, (b) peningkatan penguasaan TIK; (6) Solusi untuk Penulisan Publikasi IImiah adalah: (a) pelatihan dan pendampingan seminar hasil penelitian, (b) pelatihan dan pendampingan teknik menyusun artikel jurnal ilmiah, (c) pelatihan dan pendampingan publikasi ilmiah; (7) Solusi untuk Penilaian Keprofesian Berkelanjutan adalah: (a) sosialisasi Penilaian Keprofesian Berkelanjutan; (8) Solusi untuk Pemahaman penilaian Angka kredit adalah: (a) sosialisasi teknik penilaian angka kredit kenaikan jabatan, (b) sosialisasi dan pembimbingan pengumpulan berkas administrasi penilaian Angka Kredit untuk kenaikan jabatan.

\section{SIMPULAN}

Berdasarkan hasil analisis dan pembahasan penelitian, maka dapat disimpulkan sebagai berikut:

1. Kegiatan workshop dilaksanakan selama 3 pertemuan (12 jam) dengan materi workshop meliputi (a) teknik rumusan pemasalahan dalam PTK, (b) teknik penyusunan proposal PTK, (c) teknik pelaksanaan PTK, (d) teknik pelaporan PTK, (e) teknik penulisan publikasi ilmiah, dan (f) teknik penilaian angka kredit kenaikan jabatan fungsional guru. Sedangkan kegiatan pendampingan dilaksanakan 
setelah kegiatan workshop, dilaksanakan selama 5 pertemuan (20 jam). Pada kegiatan pendampingan ini melibatkan 3 dosen pendamping. Adapun materi pendampingan meliputi (a) pelaksanaan PTK di sekolah, (b) pelaporan PTK, (c) seminar hasil PTK, dan penulisan artikel ilmiah.

2. Metde workshop dan pendampingan dapat meningkatkan secara signifikan terhadap pemahaman dan Keterampilan PTK dalam Pengembangan Keprofesian Berkelanjutan bagi Guru Sekolah Dasar. Hal ini terbukti dari rata-rata pemahaman dan keterampilan PTK terjadi peningkatan dari 1,47 (Kurang) menjadi 3,57 (Baik).

Kendala pada pelaksanaan kegiatan workshop dan pendampingan adalah: (a) beberapa guru kurang fokus dalam mengikuti kegiatan, (b) beberapa guru kurang menguasai TIK, (c) beberapa guru kurang aktif dalam kegiatan, (d) beberapa guru masih memerlukan pendampingan yang lebih intensif. Adapun alternatif solusinya adalah: (a) kegiatan Workshop dan Pendampingan dilaksanakan pada awal semeste, (b) guru perlu bantuan/ pendampingan orang yang menguasai TIK, (c) waktu pelaksanaan tugas diperpanjang, (d) perlu pengelompokan guru berdasarkan kecapatan berfikir/usia

\section{DAFTAR PUSTAKA}

Kemendikbud. (2013). Pedoman Pelaksanaan Penilaian Kinerja Guru (PK Guru) (Buku 2). Jakarta: Kemendikbud.

Kemendikbud. (2013). Pengelolaan Pengembangan Keprofesian Berkelanjutan (Buku 1). Jakarta: Kemendikbud

Kemendikbud. (2013). Pedoman Kegiatan Pengembangan Keprofesian Berkelanjutan(PKB) (Buku 4). Jakarta: Kemendikbud.

Kemendikbud. (2013). Pedoman Penilaian Kegiatan Pengembangan Keprofesian Berkelanjutan (PKB) (Buku 5). Jakarta: Kemendikbud.

Permenneg PAN \& RB No. 16 Tahun 2009 tentang Jabatan Fungsional Guru dan Angka Kreditnya.

Peraturan Bersama Mendiknas dan Kepala BKN No: 03/V/PB/2010 dan No: 14 Tahun 2010 tentang Petunjuk Pelaksanaan Jabatan
Fungsional Guru dan Angka Kreditnya.

Permendiknas No. 35 Tahun 2010 tentang Petunjuk Teknis Pelaksanaan Jabatan Fungsional Guru dan Angka Kreditnya.

Permendiknas No. 38 Tahun 2010 tentang Penyesuaian Jabatan Fungsional Guru.

Rohendi Rohidi, T. (1992). Analisis Data Kualitatif: Terjemehan: Qualitative Data Analysis (Mathew B. Miles dan A. Michael Huberman). Jakarta: Penerbit UI Press.

Undang-Undang Nomor 20 Tahun 2003 tentang Sistem Pendidikan Nasional. Jakarta: Sinar Grafika

Undang-Undang Nomor 14 Tahun 2005 tentang Guru dan Dosen. Jakarta: Sinar Grafika 